\title{
Concentration of Thyrotropic Hormone in Persons Occupationally Exposed to Lead, Cadmium and Arsenic
}

\author{
Marta Jurdziak $^{1}$ Pawel Gać ${ }^{2}$ (D) - Małgorzata Poręba ${ }^{3}$. \\ Anna Szymańska-Chabowska ${ }^{1} \cdot$ Grzegorz Mazur $^{1} \cdot$ Rafal Porẹba $^{1}$
}

Received: 26 November 2016 / Accepted: 6 July 2017 / Published online: 19 July 2017

(C) The Author(s) 2017. This article is an open access publication

\begin{abstract}
Thyroid hormones are essential for body homeostasis. The scientific literature contains restricted proofs for effects of environmental chemical factors on thyroid function. The present study aimed at evaluating the relationship between toxicological parameters and concentration of thyrotropic hormone in persons occupationally exposed to lead, cadmium and arsenic. The studies were conducted on 102 consecutive workers occupationally exposed to lead, cadmium and arsenic (mean age $45.08 \pm 9.87$ years). The estimated parameters characterizing occupational exposure to metals included blood cadmium concentration (Cd-B), blood lead concentration $(\mathrm{Pb}-\mathrm{B})$, blood zinc protoporphyrin concentration $(\mathrm{ZnPP})$ and urine arsenic concentration (As-U). Thyroid function was evaluated using the parameter employed in screening studies, the blood thyrotropic hormone concentration (TSH). No differences were disclosed in mean values of toxicological parameters between the subgroup of persons occupationally exposed to lead, cadmium and arsenic with TSH in and out of the accepted normal values. Logistic regression demonstrated that higher blood total bilirubin concentrations $(\mathrm{ORu}=4.101$; $p=0.025)$ and higher $\mathrm{Cd}-\mathrm{B}(\mathrm{ORu}=1.532 ; p=0.027)$ represented independent risk factors of abnormal values of TSH in this group. In conclusion, in the group of workers exposed to
\end{abstract}

Paweł Gać

pawelgac@interia.pl

1 Department of Internal Medicine, Occupational Diseases and Hypertension, Wroclaw Medical University, Borowska 213, 50-556 Wroclaw, Poland

2 Department of Hygiene, Wroclaw Medical University, Mikulicza-Radeckiego 7, 50-368 Wroclaw, Poland

3 Department of Pathophysiology, Wroclaw Medical University, Marcinkowskiego 1, 50-368 Wroclaw, Poland lead, cadmium and arsenic, higher blood cadmium concentration seems to augment the risk of abnormal hormonal thyroid function.

Keywords Lead · Cadmium · Arsenic · Occupational exposure $\cdot$ Thyroid $\cdot$ Thyrotropic hormone

\section{Background}

Thyroid hormones are essential for body homeostasis and functioning of nervous, cardiovascular and reproductive systems, and they control body growth [1-3]. Their involvement remains particularly significant in development of the central nervous system (CNS), particularly of neurons in the cerebral cortex, and in development of nervous projections, their myelinization and correct blood supply in CNS [2]. Thyroid function is controlled by the hypothalamic-pituitary- thyroid axis, with mediation of thyroliberin (TRH), thyrotropic hormone (TSH), thyroxine (T4) and triiodothyronine (T3), linked by a complex network of negative feedbacks. Abnormalities in thyroid function represent a frequent pathology. Hyperthyroidism affects around $1.6 \%$ women and $0.14 \%$ men, and it ranges from 1 to $6 \%$ individuals up to 60 years of age (fivefold more frequently in women). Normal thyroid function depends on bioavailability of several trace elements, mainly iodine, providing a substrate for production of thyroid hormones and selenium (a significant element of deiodinases) but also of iron, zinc and copper [4].

The available scientific literature contains restricted proofs for effects of environmental chemical factors on thyroid function. Respective studies were conducted on polychlorinated biphenyls (PCB), phthalates, perfluorinated compounds and metals, including arsenic, cadmium, lead, manganese and 
mercury [5-15]. However, the current studies on the topic brought no unequivocal results.

The present study aimed at evaluating the relationship between toxicological parameters and thyrotropic hormone concentration (the screening index of thyroid function) in persons occupationally exposed to lead, cadmium and arsenic.

\section{Methods}

The studies were conducted during prophylactic tests in a group of 102 consecutive smelting workers who met the inclusion criteria for the project. The inclusion criteria were as follows: occupational exposure to lead, cadmium and arsenic, the total duration of employment with the exposure to metals amounting to at least 1 year and, simultaneously, the absence of the current exposure to other chemical or physical substances documented by the Safety and Hygiene section. The size and quality of the environmental exposure was similar for all of the workers included into the study. All persons inhabited the same region, at similar distances to the road traffic. The study group included only subjects who inhabited the region for a longer time (at least for 10 years). Clinical characteristics of the study group are presented in Table 1.

Basing on anamnesis and physical examination carried out in all individuals taking part in the study, personal and general information was obtained related to health condition and occupational exposure to metals.

In every participant, anthropometric measurements were conducted. Then for estimation of laboratory tests, $25 \mathrm{ml}$ of venous blood and standard urine sample from each worker right after finishing work was collected. The laboratory tests included blood cell count and conventional biochemical tests detecting serum creatinine, uric acid, aminotransferases, bilirubin, glucose, cholesterols, triglycerides, potassium and sodium. Thyroid function was evaluated using the parameter employed in screening studies, the blood thyrotropic hormone concentration (TSH). The laboratory characteristics are presented in Table 2.

The examined parameters characterized occupational exposure to metals including blood cadmium concentration (Cd-B), blood lead concentration $(\mathrm{Pb}-\mathrm{B})$, blood zinc protoporphyrin concentration (ZnPP) and urine arsenic concentration (As-U). In addition, microelements were estimated, including blood copper concentrations $(\mathrm{Cu}-\mathrm{B})$ and blood zinc concentration $(\mathrm{Zn}-\mathrm{B})$. $\mathrm{Cd}-$ $\mathrm{B}$ and $\mathrm{Pb}-\mathrm{B}$ were measured by graphite furnace atomic absorption spectrometry Solaar M6 of Thermo Elemental, UK. As-U was measured by hydride generation atomic absorption spectrometry (HGAAS) using the VP100 Continuous Flow Vapour System. $\mathrm{Cu}-\mathrm{B}$ and $\mathrm{Zn}-\mathrm{B}$ were determined by flame atomic absorption spectrometry (Thermo Elemental Solaar M6, UK). $\mathrm{ZnPP}$ erythrocyte concentration was measured using a rapid, fluorometric screening method by means of a ProtoFluor hematofluorometer by Helena (USA). Concentrations of metals and metalloid in samples of blood or urine in the study group are shown in Table 3.

In subsequent stages of the study, using as cutoff levels normative values of TSH (reference range of $0.4-4.0 \mathrm{mIU} / \mathrm{l}$ ), in persons occupationally exposed to lead, cadmium and arsenic, two subgroups were distinguished: those with abnormal
Table 1 Clinical characteristics of the study group

\begin{tabular}{|c|c|c|c|c|c|}
\hline & Mean & Median & $\begin{array}{l}\text { Standard } \\
\text { deviation }\end{array}$ & Minimum & Maximum \\
\hline Age (years) & 45.08 & 46.00 & 9.87 & 25.00 & 63.00 \\
\hline Height (m) & 1.75 & 1.76 & 0.08 & 1.59 & 1.93 \\
\hline Body mass (kg) & 90.67 & 90.00 & 19.71 & 51.00 & 140.00 \\
\hline Body mass index $\left(\mathrm{kg} / \mathrm{m}^{2}\right)$ & 29.34 & 29.60 & 5.23 & 18.30 & 45.20 \\
\hline Body surface area $\left(\mathrm{m}^{2}\right)$ & 2.06 & 2.04 & 0.24 & 1.55 & 2.63 \\
\hline \multirow[t]{2}{*}{ Waist circumference $(\mathrm{cm})$} & 102.08 & 102.00 & 14.93 & 67.00 & 138.00 \\
\hline & $n$ & & $\%$ & & \\
\hline \multicolumn{6}{|l|}{ Gender } \\
\hline Men & 83 & & 81.4 & & \\
\hline Women & 19 & & 19.6 & & \\
\hline Smoking & 45 & & 44.12 & & \\
\hline Overweight/obesity & 75 & & 73.5 & & \\
\hline Overweight & 29 & & 28.4 & & \\
\hline Obesity & 46 & & 45.1 & & \\
\hline Arterial hypertension & 43 & & 42.2 & & \\
\hline Coronary artery diseases & 4 & & 3.9 & & \\
\hline Dyslipidaemia & 9 & & 8.8 & & \\
\hline Diabetes & 11 & & 10.8 & & \\
\hline
\end{tabular}


Table 2 Laboratory parameters in the study group

\begin{tabular}{|c|c|c|c|c|c|}
\hline & Mean & Median & $\begin{array}{l}\text { Standard } \\
\text { deviation }\end{array}$ & Minimum & Maximum \\
\hline White blood cells (G/1) & 7.44 & 7.33 & 1.64 & 4.62 & 14.32 \\
\hline Red blood cells (T/l) & 4.98 & 4.92 & 0.36 & 4.13 & 5.73 \\
\hline Haemoglobin (g/dl) & 15.10 & 15.30 & 1.12 & 11.50 & 18.30 \\
\hline Platelet count (G/l) & 235.58 & 236.50 & 60.13 & 56.00 & 431.00 \\
\hline Total bilirubin (mg/dl) & 0.63 & 0.60 & 0.26 & 0.20 & 1.60 \\
\hline Alanine aminotransferase (U/l) & 36.72 & 32.50 & 17.70 & 9.00 & 93.00 \\
\hline Aspartate aminotransferase (U/l) & 31.21 & 28.50 & 15.63 & 13.00 & 141.00 \\
\hline Glucose (mg/dl) & 102.36 & 91.00 & 36.66 & 63.00 & 299.00 \\
\hline Creatinine (mg/dl) & 1.07 & 1.08 & 0.15 & 0.80 & 1.65 \\
\hline eGFR (ml/min) & 76.25 & 74.50 & 11.45 & 45.00 & 105.00 \\
\hline Uric acid (mg/dl) & 6.28 & 6.40 & 1.48 & 2.90 & 9.70 \\
\hline Total cholesterol (mg/dl) & 232.85 & 230.50 & 56.61 & 87.00 & 539.00 \\
\hline High-density lipoprotein (mg/dl) & 48.44 & 47.00 & 12.51 & 27.00 & 89.00 \\
\hline Low-density lipoprotein (mg/dl) & 138.39 & 138.00 & 39.26 & 24.00 & 237.00 \\
\hline Triglycerides (mg/dl) & 262.71 & 178.00 & 253.21 & 50.00 & 1513.00 \\
\hline TSH (mIU/l) & 2.18 & 1.96 & 1.13 & 0.55 & 6.19 \\
\hline Potassium (mmol/l) & 4.79 & 4.74 & 0.42 & 3.73 & 5.91 \\
\hline Sodium $(\mathrm{mmol} / \mathrm{l})$ & 139.21 & 139.00 & 2.14 & 131.00 & 144.00 \\
\hline
\end{tabular}

eGFR estimated glomerular filtration rate, TSH thyrotropic hormone values of TSH and with normal TSH. Using the criterion of 1st and 2nd tercile of TSH, three subgroups were distinguished: manifesting TSH $<1$ st tercile, TSH between 1 st and 2 nd tercile and those with $\mathrm{TSH} \geq 2$ nd tercile.

Statistical analysis was conducted using the software of STATISTICA 10 (StatSoft Polska). Distribution of the variables was tested using tests of Lilliefors and Shapiro-Wilk. In cases of independent quantitative variables manifesting normal distribution, the subsequent statistical analysis used the $t$ test for unlinked variables or the univariable, parametric analysis of variance. In cases of variables manifesting distribution distinct than the normal one, analysis of independent quantitative variables employed the $U$ test of Mann-Whitney or a non-parametric equivalent of analysis of variance, the Kruskal-Wallis test. Significant statistical differences between arithmetic means were estimated using the post hoc test of Newman-Keuls. For independent qualitative variables, the subsequent statistical analysis used the chi-square test of the highest credibility. For determination of relationships between studied variables, analysis of logistic regression was conducted. Results at the level of $p<0.05$ were accepted as significant.

\section{Results}

In the study group of persons occupationally exposed to lead, cadmium and arsenic, mean Cd-B amounted to $2.34 \mu \mathrm{g} / \mathrm{l}$, mean As-U was $14.31 \mu \mathrm{g} / \mathrm{g}$ crea, mean $\mathrm{Pb}-\mathrm{B}$ was $222.09 \mu \mathrm{g} / \mathrm{l}$ and mean $\mathrm{ZnPP}$ was $42.67 \mu \mathrm{g} / \mathrm{dl}$. Toxicological parameters in the
Table 3 Concentrations of metals and metalloid in samples of blood or urine in the study group

\begin{tabular}{lrrrrr}
\hline & Mean & Median & $\begin{array}{c}\text { Standard } \\
\text { deviation }\end{array}$ & Minimum & Maximum \\
\hline Duration of work with exposure (years) & 16.34 & 14.00 & 11.53 & 1.00 & 43.00 \\
$\mathrm{Cu}-\mathrm{B}(\mathrm{mg} / \mathrm{dl})$ & 111.50 & 110.50 & 18.27 & 84.00 & 139.00 \\
$\mathrm{Zn}-\mathrm{B}(\mathrm{mg} / \mathrm{dl})$ & 84.42 & 81.60 & 9.70 & 71.90 & 99.90 \\
$\mathrm{Cd}-\mathrm{B}(\mu \mathrm{g} / \mathrm{l})$ & 2.34 & 0.71 & 3.16 & 0.34 & 8.23 \\
$\mathrm{As}-\mathrm{U}(\mu \mathrm{g} / \mathrm{g}$ crea) & 14.31 & 10.90 & 12.51 & 2.43 & 89.50 \\
$\mathrm{~Pb}-\mathrm{B}(\mu \mathrm{g} / \mathrm{l})$ & 222.09 & 222.00 & 140.98 & 16.60 & 638.00 \\
$\mathrm{ZnPP}(\mu \mathrm{g} / \mathrm{dl})$ & 42.67 & 34.00 & 28.94 & 17.00 & 203.00 \\
\hline
\end{tabular}

$A s-U$ concentration of arsenic in urine, $C d-B$ concentration of cadmium in blood, $C u-B$ concentration of copper in blood, $P b-B$ concentration of lead in blood, $Z n-B$ concentration of zinc in blood, $Z n P P$ concentration of zinc protoporphyrin in blood 
studied group of individuals occupationally exposed to lead, cadmium and arsenic are presented in Table 3.

No differences were disclosed in mean values of toxicological parameters between the subgroups of persons occupationally exposed to lead, cadmium and arsenic with TSH in and out of the accepted normal values. Toxicological parameters in the subgroups distinguished basing on the criterion of normal values of thyrotropic hormone in blood are presented in Table 4.

Also, no differences were disclosed in mean values of toxicological parameters between subgroups of persons with TSH $<1$ st tercile, TSH between the 1st and the 2nd tercile and those with $\mathrm{TSH} \geq 2$ nd tercile. The toxicological parameters in subgroups distinguished on the basis of 1st and 2nd tercile of TSH are presented in Table 5 .

Logistic non-linear regression yielded the following model, taking into account anthropological parameters (age and BMI), biochemical parameters (glucose, total bilirubin, alanine and aspartate aminotransferases, creatinine and uric acid, total cholesterol, HDL cholesterol and

Table 4 Toxicological parameters in subgroups distinguished basing on the criterion of normative values of thyrotropic hormone in blood

\begin{tabular}{|c|c|c|c|}
\hline & Abnormal TSH & Normal TSH & $p$ \\
\hline $\mathrm{Cd}-\mathrm{B}(\mu \mathrm{g} / \mathrm{l})^{\mathrm{a}}$ & $4.54 \pm 5.21$ & $1.90 \pm 2.60$ & 0.277 \\
\hline Cd-B $\geq 1$ st quartile ${ }^{b}$ & 100.0 & 80.0 & 0.488 \\
\hline $\mathrm{Cd}-\mathrm{B} \geq$ median $^{\mathrm{b}}$ & 100.0 & 40.0 & 0.121 \\
\hline Cd-B $\geq 3$ rd quartile ${ }^{b}$ & 50.0 & 30.0 & 0.584 \\
\hline $\mathrm{Cd}-\mathrm{B}>\mathrm{MAC}^{\mathrm{b}}$ & 50.0 & 10.0 & 0.166 \\
\hline As-U $(\mu \mathrm{g} / \mathrm{g} \text { crea })^{\mathrm{a}}$ & $10.83 \pm 7.82$ & $14.59 \pm 12.80$ & 0.447 \\
\hline As- $U \geq 1$ st quartile ${ }^{b}$ & 57.1 & 77.3 & 0.231 \\
\hline As- $U \geq$ median $^{\mathrm{b}}$ & 28.6 & 52.3 & 0.227 \\
\hline As- $U \geq 3$ rd quartile ${ }^{b}$ & 14.3 & 26.1 & 0.487 \\
\hline As-U $>$ MAC $^{\mathrm{b}}$ & 0.0 & 6.8 & 0.475 \\
\hline $\mathrm{Pb}-\mathrm{B}(\mu \mathrm{g} / \mathrm{l})^{\mathrm{a}}$ & $217.88 \pm 87.45$ & $222.45 \pm 144.94$ & 0.930 \\
\hline $\mathrm{Pb}-\mathrm{B} \geq 1$ st quartile $\mathrm{b}^{\mathrm{b}}$ & 87.5 & 74.5 & 0.411 \\
\hline $\mathrm{Pb}-\mathrm{B} \geq$ median $^{\mathrm{b}}$ & 62.5 & 48.9 & 0.461 \\
\hline $\mathrm{Pb}-\mathrm{B} \geq 3$ rd quartile $\mathrm{b}^{\mathrm{b}}$ & 12.5 & 27.6 & 0.351 \\
\hline $\mathrm{Pb}-\mathrm{B}>\mathrm{MAC}^{\mathrm{b}}$ & 0.0 & 4.3 & 0.552 \\
\hline $\mathrm{ZnPP}(\mu \mathrm{g} / \mathrm{dl})^{\mathrm{a}}$ & $37.00 \pm 13.42$ & $43.15 \pm 29.88$ & 0.567 \\
\hline $\mathrm{ZnPP} \geq 1$ st quartile ${ }^{\mathrm{b}}$ & 75.0 & 75.5 & 0.973 \\
\hline $\mathrm{ZnPP} \geq$ median $^{\mathrm{b}}$ & 50.0 & 51.0 & 0.954 \\
\hline $\mathrm{ZnPP} \geq 3$ rd quartile $\mathrm{e}^{\mathrm{b}}$ & 25.0 & 25.5 & 0.974 \\
\hline $\mathrm{ZnPP} \geq \mathrm{MAC}^{\mathrm{b}}$ & 0.0 & 9.6 & 0.359 \\
\hline
\end{tabular}

$A s-U$ concentration of arsenic in urine, $C d-B$ concentration of cadmium in blood, $C u-B$ concentration of copper in blood, $M A C$ maximum admissible concentrations, $P b-B$ concentration of lead in blood, $T S H$ thyrotropic hormone, $Z n-B$ concentration of zinc in blood, $Z n P P$ concentration of zinc protoporphyrin in blood

${ }^{\mathrm{a}}$ Arithmetic mean \pm standard deviation

${ }^{\mathrm{b}}$ Percentage triglycerides) and toxicological parameters (Cd-B, $\mathrm{Pb}-\mathrm{B}$, $\mathrm{ZnPP}$ and As-U):

logit abnormal TSH $=1.496$ total bilirubin $+1.262 \mathrm{Cd}-\mathrm{B}$

The obtained model demonstrated that higher blood total bilirubin concentrations and higher $\mathrm{Cd}-\mathrm{B}$ represented independent risk factors of abnormal values of TSH in this group. Complete logistic regression analysis results are presented in Table 6.

\section{Discussion}

Analysis of results obtained in this study justifies the statement that in the group of workers exposed to lead, cadmium and arsenic, a relationship between blood cadmium concentration and blood thyrotropic hormone concentration exists, but this relation is a non-linear one. A further analysis has shown that in the studied group no relationships existed between the other toxicological parameters and blood thyrotropic hormone concentration. Comparative analyses did not reveal any statistically significant differences in toxicological parameters between subgroups of patients with different blood TSH concentrations. Nevertheless, in parallel, analysis of non-linear logistic regression has demonstrated that higher blood cadmium concentrations, aside from higher blood total bilirubin concentration, represented an independent risk factor of abnormal blood thyrotropic hormone concentrations.

The results of the present study may significantly supplement current knowledge on the relationship between exposure to metals and thyroid function. As abovementioned, the studies on the subject do not allow an unequivocal confirmation of such a relationship [5-7, 16, 17].

Lead represents one of the better examined heavy metals, as far as their effect on thyroid hormone concentrations is considered. Studies conducted on a population exposed to high lead concentrations (lead concentration in blood $\geq 50 \mu \mathrm{g} / \mathrm{dl}$ ) suggested a negative relationship between lead concentration in blood and concentrations of T4, fT4 and T3 hormones [17-19]. Zadjali et al. also showed that the exposure of diabetic rats to lead acetate caused changes that are consistent with clinical hypothyroidism i.e. high TSH and low T4 and T3 levels [20]. In turn, studies independently conducted by e.g. Erfurth et al., Schumacher et al. and Refowitz et al., on a similar population detected no significant relationship between the variables [21-24]. Results of a few investigations are also available, in which the relationship was examined between lead concentration in blood and thyroid function in populations manifesting $\mathrm{Pb}-\mathrm{B}<10 \mu \mathrm{g} / \mathrm{dl}$. In such a population, Dundar et al. documented a negative correlation between $\mathrm{Pb}-\mathrm{B}$ and $\mathrm{fT} 4$ [7]. Meeker et al. proved in 
Table 5 Toxicological parameters in subgroups distinguished basing on the criterion of values of the first and the second terciles of thyrotropic hormone concentrations in blood

Table 6 Results of logistic regression analysis

\begin{tabular}{|c|c|c|c|c|}
\hline & $\mathrm{TSH}<1$ st tercile & TSH: 1 st-2nd tercile & $\mathrm{TSH} \geq 2$ nd tercile & $p$ \\
\hline $\mathrm{Cd}-\mathrm{B}(\mu \mathrm{g} / \mathrm{l})^{\mathrm{a}}$ & $0.86 \pm 0.00$ & $3.05 \pm 4.48$ & $2.26 \pm 2.82$ & 0.841 \\
\hline $\mathrm{Cd}-\mathrm{B} \geq 1$ st quartile ${ }^{\mathrm{b}}$ & 100.0 & 100.0 & 75.0 & 0.549 \\
\hline Cd-B $\geq$ median $^{\mathrm{b}}$ & 100.0 & 33.3 & 50.0 & 0.513 \\
\hline Cd-B $\geq 3$ rd quartile ${ }^{b}$ & 0.0 & 33.3 & 37.5 & 0.755 \\
\hline $\mathrm{Cd}-\mathrm{B}>\mathrm{MAC}^{\mathrm{b}}$ & 0.0 & 33.3 & 12.5 & 0.638 \\
\hline As-U $(\mu \mathrm{g} / \mathrm{g} \text { crea })^{\mathrm{a}}$ & $15.01 \pm 12.13$ & $13.38 \pm 8.71$ & $14.67 \pm 16.11$ & 0.862 \\
\hline As- $U \geq 1$ st quartile ${ }^{b}$ & 75.9 & 79.4 & 71.9 & 0.775 \\
\hline As- $U \geq$ median $^{\mathrm{b}}$ & 58.6 & 55.9 & 37.5 & 0.190 \\
\hline As- $\mathrm{U} \geq 3$ rd quartile $\mathrm{b}^{\mathrm{b}}$ & 34.5 & 17.7 & 25.0 & 0.309 \\
\hline $\mathrm{As}-\mathrm{U}>\mathrm{MAC}^{\mathrm{b}}$ & 3.5 & 5.9 & 9.4 & 0.631 \\
\hline $\mathrm{Pb}-\mathrm{B}(\mu \mathrm{g} / \mathrm{l})^{\mathrm{a}}$ & $204.38 \pm 147.94$ & $255.45 \pm 155.12$ & $204.95 \pm 114.11$ & 0.098 \\
\hline $\mathrm{Pb}-\mathrm{B} \geq 1$ st quartile ${ }^{\mathrm{b}}$ & 60.6 & 88.6 & 76.5 & 0.067 \\
\hline $\mathrm{Pb}-\mathrm{B} \geq$ median $^{\mathrm{b}}$ & 48.5 & 57.1 & 44.1 & 0.545 \\
\hline $\mathrm{Pb}-\mathrm{B} \geq 3$ rd quartile ${ }^{\mathrm{b}}$ & 30.3 & 31.4 & 17.6 & 0.359 \\
\hline $\mathrm{Pb}-\mathrm{B}>\mathrm{MAC}^{\mathrm{b}}$ & 3.0 & 8.6 & 0.0 & 0.177 \\
\hline $\mathrm{ZnPP}(\mu \mathrm{g} / \mathrm{dl})^{\mathrm{a}}$ & $41.09 \pm 22.07$ & $50.69 \pm 41.84$ & $35.94 \pm 13.01$ & 0.227 \\
\hline $\mathrm{ZnPP} \geq 1$ st quartile $\mathrm{e}^{\mathrm{b}}$ & 75.8 & 80.0 & 70.6 & 0.661 \\
\hline $\mathrm{ZnPP} \geq$ median $^{\mathrm{b}}$ & 54.6 & 57.1 & 41.2 & 0.366 \\
\hline $\mathrm{ZnPP} \geq 3$ rd quartile $\mathrm{b}$ & 27.3 & 28.6 & 20.6 & 0.719 \\
\hline $\mathrm{ZnPP} \geq \mathrm{MAC}^{\mathrm{b}}$ & 9.1 & 17.1 & 0.0 & 0.053 \\
\hline
\end{tabular}

$A s-U$ concentration of arsenic in urine, $C d-B$ concentration of cadmium in blood, $C u$ - $B$ concentration of copper in blood, MAC maximum admissible concentrations, $P b-B$ concentration of lead in blood, $T S H$ thyrotropic hormone, $Z n-B$ concentration of zinc in blood, $Z n P P$ concentration of zinc protoporphyrin in blood

${ }^{\text {a }}$ Arithmetic mean \pm standard deviation

${ }^{\mathrm{b}}$ Percentage

\begin{tabular}{|c|c|c|c|c|}
\hline & \multicolumn{4}{|c|}{ Model for Probability of abnormal TSH } \\
\hline & Regression coefficient & SEM of Rc & $p$ value & $\begin{array}{l}\text { Odds ratio } \\
\text { (for unit change) }\end{array}$ \\
\hline Intercept & 1.376 & 6.566 & 0.834 & 3.960 \\
\hline Age (years) & -0.093 & 0.067 & 0.171 & 0.911 \\
\hline Body mass index $\left(\mathrm{kg} / \mathrm{m}^{2}\right)$ & 0.024 & 0.141 & 0.863 & 1.025 \\
\hline Glucose (mg/dl) & -0.035 & 0.033 & 0.292 & 0.965 \\
\hline Total bilirubin (mg/dl) & 1.496 & 5.038 & 0.025 & 4.101 \\
\hline Alanine aminotransferase (U/l) & 0.042 & 0.044 & 0.343 & 1.043 \\
\hline Aspartate aminotransferase (U/1) & 0.002 & 0.069 & 0.977 & 1.002 \\
\hline Creatinine (mg/dl) & 0.173 & 4.425 & 0.969 & 1.189 \\
\hline Uric acid (mg/dl) & 0.566 & 0.639 & 0.378 & 1.761 \\
\hline Total cholesterol (mg/dl) & 0.010 & 0.017 & 0.571 & 1.010 \\
\hline High density lipoprotein (mg/dl) & -0.009 & 0.076 & 0.910 & 0.991 \\
\hline Triglycerides (mg/dl) & -0.001 & 0.003 & 0.844 & 0.999 \\
\hline $\mathrm{Cd}-\mathrm{B}(\mu \mathrm{g} / \mathrm{l})$ & 1.262 & 0.562 & 0.027 & 1.532 \\
\hline As- $\mathrm{U}(\mu \mathrm{g} / \mathrm{g}$ crea $)$ & -0.022 & 0.046 & 0.626 & 0.978 \\
\hline $\mathrm{Pb}-\mathrm{B}(\mu \mathrm{g} / \mathrm{l})$ & 0.004 & 0.006 & 0.473 & 1.004 \\
\hline $\mathrm{ZnPP}(\mu \mathrm{g} / \mathrm{dl})$ & -0.063 & 0.052 & 0.231 & 0.939 \\
\hline
\end{tabular}

$A s-U$ concentration of arsenic in urine, $C d-B$ concentration of cadmium in blood, $P b-B$ concentration of lead in blood, SEM of Rc standard error of the regression coefficient, TSH thyrotropic hormone, ZnPP concentration of zinc protoporphyrin in blood 
turn a negative relationship between $\mathrm{Pb}-\mathrm{B}$ and TSH [10], while Mendy et al. demonstrated a negative relationship between $\mathrm{Pb}-\mathrm{B}$ and total thyroxin as well as absence of a significant correlation between $\mathrm{Pb}-\mathrm{B}$ and TSH, TT3, fT3 and fT4 [25]. A similar absence of a significant relationship between $\mathrm{Pb}-\mathrm{B}$ and concentration of thyroid hormones in blood was found by Chen et al. [26]. Abdelouahab et al. identified absence of a significant relationship between thyroid hormone concentrations and concentration of lead in men. On women, on the other hand, a positive relationship was disclosed between $\mathrm{Pb}-\mathrm{B}$ and $\mathrm{T} 3$ and a negative one between $\mathrm{Pb}-\mathrm{B}$ and TSH [27]. A similar conclusion resulted from studies conducted by Schell et al., who documented also a positive relationship between $\mathrm{Pb}$ $\mathrm{B}$ and T3 (mean lead concentration of $1.3 \pm 0.15 \mu \mathrm{g} / \mathrm{dl}$ ); in turn, Singh detected a positive relationship between $\mathrm{Pb}$ $\mathrm{B}$ and TSH (mean lead concentration of $51.9 \pm 9.4 \mu \mathrm{g} / \mathrm{dl}$ ) $[28,29]$. The discussed studies seemed to exclude any relationship between concentrations of lead and zinc protoporphyrin in blood and concentration of thyrotropic hormone in a population exposed to lead, cadmium and arsenic.

Exposure to cadmium may induce either acute or chronic damage of several organs, first of all liver, kidneys, lungs, bones and testes. However, the available literature contains also certain data suggesting negative influence of cadmium on thyroid gland [6, 11, 26, 30-34]. Rasic-Milutinovic et al. showed a potential toxic effect of cadmium on thyroid function in Hashimoto thyroiditis patients [35]. Studies conducted on animals exposed to cadmium pointed to lowered concentrations of TT4 or TT4 and TT3 in serum [31-33]. The suggested mechanism explaining the described effect might involve e.g. inhibition of synthesis and/or release of thyroxin, a disturbed process of $\mathrm{T} 4$ deiodination due to inhibited activity of 5-deiodinase [33]. In studies of Hammoudy et al. on experimental animals, supplementation with selenium and zinc reduced the cadmium-induced thyroid dysfunction [31, 32]. Interesting were also results of studies by Gupta and Kar, who provided evidence for a protective effect exerted by administration of ascorbic acid, which reduced the cadmiuminduced decrease in serum T3 concentration, reduction of hepatic deiodinase activity and augmented peroxidation of cell membrane lipids. The effect resulted from antioxidative effects of ascorbic acid [33]. Mohamed et al. demonstrated significantly increased levels of TSH in Cd-treated rats compared with the control group. The addition of phytic acid in diet decreased the high levels of TSH [36]. Chen et al., in studies performed within the National Health and Nutrition Examination Survey (NHANES) in 2007-2008 in USA on a group of around 5000 individuals, demonstrated a positive relationship between cadmium concentration in urine and concentrations of TT4, TT3, fT3 and thyroglobulin [26]. In turn, studies performed by Ijima et al. in groups of 24 women and
24 newborns showed that concentration of cadmium in umbilical blood showed a significant negative correlation with concentration of TSH in blood of the newborns [6]. Christensen et al. described a negative correlation between cadmium concentration in blood and concentration of TSH and a positive correlation between concentration of cadmium in urine and concentrations of T3 and fT3. No significant relationship was demonstrated between cadmium concentration in blood and concentration of TSH in studies of Meeker et al. conducted on 219 men, patients of an infertility clinic [10]. The abovementioned studies, as it was already accentuated, point to a non-linear relationship between elevated cadmium concentration in blood and abnormal concentrations of thyrotropic hormone in a population of individuals exposed to lead, cadmium and arsenic.

Epidemiological studies link chronic exposure to arsenic first of all to increased incidence of tumours, such as neoplasms of lungs, urinary bladder, skin and liver, and of several other diseases, including coronary artery disease, diabetes, infertility and neurological and dementive diseases $[5,37-40]$. In the context of thyroid function, the available studies demonstrated that at the cellular level arsenic disturbs gene control taking place with mediation of steroid hormone receptors and receptors of retinoic acid and of thyroid hormones [5, 41, 42]. In turn, Palazzolo et al. confirmed the ability of arsenic trioxide to inhibit the activity of TPO in vitro [43]. Sun et al. showed that arsenic concentrations at $\leq 150 \mu \mathrm{g} / 1$ interfered with thyroid hormone homeostasis in bighead carp larvae by increasing thyroid hormone levels and reducing Trs mRNA transcriptional levels [44]. Additionally, it has been demonstrated that arsenite caused oxidative damage, affected thyroid endocrine system and altered gene transcription in the hypothalamicpituitary-thyroid axis in zebrafish [45]. Investigations of Kotyzova et al. failed to demonstrate effects of selenium and iodine supplementation on storage of arsenic in rat thyroid glands (in cases of exposure to bromine supplementation with iodine and selenium induced 50\% reduction of bromine uptake by thyroid gland). On the other hand, exposure to arsenic induced an increase in iodine concentration and a decrease in selenium concentration in thyroids of animals administered with iodine and selenium [46]. Meeker et al. described a positive relationship between arsenic concentration in blood and serum TSH concentration in 219 men, patients of an infertility clinic. The effect was dependent on the dose [10]. The discussed investigations seem to exclude a relationship between arsenic concentration in urine and concentration of thyrotropic hormone in the population of individuals exposed to lead, cadmium and arsenic.

The main limitation of the study is the absence of a control group composed of individuals who are not exposed to metals at the workplace, with similar clinical characteristics and 
comparable environmental exposure to metals, failure to measure the level of other thyroid hormones (fT3 and fT4) and a complex character of the exposure (parallel exposure to lead, cadmium and arsenic).

Summing up the above, the obtained results of investigations may prompt further studies related to relationships between exposure to various chemical agents and thyroid function, particularly in the context of parallel exposure to low concentrations of various substances. The data related to the relationship between exposure to lead, cadmium and arsenic remain incomplete, and, as proven also by this study, they are frequently equivocal or even contradictory. As far as exposure to other metals affects thyroid function, we have at our disposal only individual reports pertaining exposure to mercury, manganese, molybdenum, barium, thallium, caesium and uranium $[8,11]$. Moreover, the idea to conduct population-based studies should be postulated, related to such relationships.

\section{Conclusion}

1. In the group of workers exposed to lead, cadmium and arsenic, a relationship between blood cadmium concentration and blood thyrotropic hormone concentration has been documented, but this relation is a non-linear one.

2. In the group of workers exposed to lead, cadmium and arsenic, higher blood cadmium concentration seems to augment the risk of abnormal hormonal thyroid function.

\section{Compliance with Ethical Standards}

Funding All funds for the study came from Wroclaw Medical University local grants.

Conflict of Interest The authors declare that they have no conflict of interest.

Ethical Approval All procedures performed in studies involving human participants were in accordance with the ethical standards of the institutional research committee (Local Bioethical Committee in Wroclaw Medical University) and with the 1964 Helsinki Declaration and its later amendments or comparable ethical standards.

Informed consent Informed consent was obtained from all individual participants included in the study.

Open Access This article is distributed under the terms of the Creative Commons Attribution 4.0 International License (http:// creativecommons.org/licenses/by/4.0/), which permits unrestricted use, distribution, and reproduction in any medium, provided you give appropriate credit to the original author(s) and the source, provide a link to the Creative Commons license, and indicate if changes were made.

\section{References}

1. Danzi S, Klein I (2012) Thyroid hormone and cardiovascular system. Med Clin North Am 96:257-268

2. Williams GR (2008) Neurodevelopmental and neurophysiological actions of thyroid hormone. J Neuroendocrinol 20:784-794

3. Yazbeck CF, Sullivan SD (2012) Thyroid disorders during pregnancy. Med Clin North Am 96:235-256

4. Arthur JD, Beckett GJ (1999) Thyroid function. Br Med Bull 55: 658-668

5. Davey JC, Nomikos AP, Wungjiranirun M et al (2008) Arsenic as an endocrine disruptor: arsenic disrupts retinoic acid receptor- and thyroid hormone receptor- mediated gene regulation and thyroid hormone-mediated amphibian tail metamorphosis. Environ Health Perspect 116:165-712

6. Iijima K, Otake J, Ikegami M et al (2007) Cadmium, lead, selenium in cord blood and thyroid hormone status of newborns. Biol Trace Elem Res 119:10-18

7. Dundar B, Oktem F, Arslan MK et al (2006) The effect of long term low-dose lead exposure on thyroid function in adolescents. Environ Res 101:140-145

8. Soldin OP, Aschner M (2007) Effects of manganese on thyroid hormone homeostasis: potential links. Neurotoxicology 28: 951-956

9. Soldin OP, O'Mara DM, Aschner M (2008) Thyroid hormones and methylmercury toxicity. Biol Trace Elem Res 126:1-12

10. Meeker JD, Rossano MG, Protas B et al (2009) Multiple metals predict prolactin and thyrotropin (TSH) levels in men. Environ Res 109:869-873

11. Yorita Christensen KL (2012) Metals in blood and urine, and thyroid function among adults in the United States 2007-2008. Int J Hyg Environ Health 216:624-632

12. Blount BC, Pirkle JL, Osterloh JD et al (2006) Urinary perchlorate and thyroid hormone levels in adolescent and adult men and women living in the United States. Environ Health Perspect 114:1865-1871

13. Boas M, Main KM, Feldt-Rasmussen U (2009) Environmental chemicals and thyroid function. Eur J Endocrinol 16:385-391

14. Brucker-Davis F (1998) Effects of environmental synthetic chemicals on thyroid function. Thyroid 8:827-856

15. Zoeller RT (2005) Environmental chemicals as thyroid hormone analogues: new studies indicate that thyroid hormone receptors are targets of industrial chemicals? Mol Cell Endocrinol 242:10-15

16. Lamb MR, Janevic T, Liu X et al (2008) Environmental lead exposure, maternal thyroid function and childhood growth. Environ Res 106:195-202

17. Robins JM, Cullen MR, Connors BB et al (1983) Depressed thyroid indexes associated with occupational exposure to inorganic lead. Arch Intern Med 143:220-224

18. Lopez CM, Pineiro AE, Nunez N et al (2000) Thyroid hormone changes in males exposed to lead in Buenos Aires area (Argentina). Pharmacol Res 42:599-602

19. Tuppurainen M, Wagar G, Kurppa K et al (1988) Thyroid function as assessed by routine laboratory tests of workers with long-term lead exposure. Scand J Work Environ Health 14:175-180

20. Zadjali SA, Nemmar A, Fahim MA et al (2015) Lead exposure causes thyroid abnormalities in diabetic rats. Int J Clin Exp Med 8:7160-7167

21. Erfurth EM, Gerhardsson L, Nilsson A et al (2001) Effects of lead on the endocrine system in lead smelter workers. Arch Environ Health 56:449-455

22. Schumacher C, Brodkin CA, Alexander B et al (1998) Thyroid function in lead smelter workers: abscence of subacute or cumulative effects with moderate lead burdens. Int Arch Occup Environ Health 71:453-458 
23. Refowitz RM (2000) Thyroid function and lead: no clear relationship. Biometals 13:187-192

24. Krieg EF Jr (2016) A meta-analysis of studies investigating the effects of occupational lead exposure on thyroid hormones. Am J Ind Med 59:583-590

25. Mendy A, Gasana J, Vieira ER (2009) Low blood lead concentrations and thyroid function of American adults. J Endocrionol Investig 32:175-183

26. Chen A, Kim SS, Chung E et al (2013) Thyroid hormones in relation to lead, mercury and cadmium exposure in the National Health and Nutrition Examination Survey, 2007-2008. Environ Health Perspect 121:181-186

27. Abdelouahab N, Mergler D, Takser L et al (2008) Gender differences in the effects of organochlorines, mercury and lead on thyroid hormone levels in lakeside communities of Quebec (Canada). Environ Res 107:380-392

28. Schell LM, Gallo MV, Denham M et al (2008) Relationship of thyroid hormone levels to levels of polychlorinated biphenyls, lead, p,p'-DDE and other toxicants in Akwesasne Mohawk Youth. Environ Health Perspect 116:806-813

29. Singh B, Chandran V, Bandhu HK et al (1984) Impact of lead exposure on pituitary-thyroid axis in humans. Arch Environ Health 39:431-440

30. Gerhard I, Waibel S, Daniel V et al (1998) Impact of heavy metals on hormonal and immunological factors in women with repeated miscarriages. Hum Reprod Update 4:301-309

31. Mori K, Yoshida K, Hoshikawa S et al (2006) Effects of perinatal exposure to low doses of cadmium or methylmercury on thyroid hormone metabolism in metallothionein-deficient mouse neonates. Toxicology 228:77-84

32. Hammouda F, Messaoudi I, El Hani J et al (2008) Reversal of cadmium-induced thyroid dysfunction by selenium, zinc or their combination in rat. Biol Trace Elem Res 126:194-203

33. Gupta P, Kar A (1998) Role of ascorbic acid in cadmium-induced thyroid dysfunction and lipid peroxidation. J Appl Toxicol 18: 317-320

34. Yoshizuka M, Mori N, Hamasaki K et al (1991) Cadmium toxicity in the thyroid gland of pregnant rats. Exp Mol Pathol 55:97-104
35. Rasic-Milutinovic Z, Jovanovic D, Bogdanovic G et al (2017) Potential influence of selenium, copper, zinc and cadmium on 1thyroxine substitution in patients with hashimoto thyroiditis and hypothyroidism. Exp Clin Endocrinol Diabetes 125:79-85

36. Mohamed TM, Salama AF, El Nimr TM et al (2015) Effects of phytate on thyroid gland of rats itoxicated with cadmium. Toxicol Ind Health 31:1258-1268

37. Abernathy CO, Thomas DJ, Calderon RL (2003) Health effects and risk assessment of arsenic. J Nutr 133(supp11):1536S-1538S

38. Smith AH, Hoppenhayn-Rich C, Bates MN et al (2002) Cancer risks from arsenic in drinking water. Environ Health Perspect 97: 259-267

39. Tapio S, Grosche B (2006) Arsenic in the aethiology of cancer. Mutat Res 612:215-246

40. Watanabe C, Inaoka T, Matsui T et al (2003) Effects of arsenic on younger generations. J Environ Sci Health 38:129-139

41. Davey JC, Bodwell JE, Gosse JA et al (2007) Arsenic as an endocrine disruptor: effects of arsenic on estrogen receptor- mediated gene expression in vivo and in cell culture. Toxicol Sci 98:75-86

42. Kaltreider RC, Davis AM, Lariviere JP et al (2001) Arsenic alters the function of the glucocorticoid receptor as a transcription factor. Environ Health Perspect 109:245-251

43. Palazzolo DL, Jansen KP (2008) The minimal arsenic concentration required to inhibit the activity of thyroid peroxidase in vitro. Biol Trace Elem Res 126:49-55

44. Sun HJ, Xiang P, Tang MH et al (2016) Arsenic impacted the development, thyroid hormone and gene transcription of thyroid hormone receptors in bighead carp larvae (Hypophthalmichthys nobilis). J Hazard Mater 303:76-82

45. Sun HJ, Li HB, Xiang P et al (2015) Short term exposure of arsenite disrupted thyroid endocrine system and altered gene transcription in the HPT axis in zebrafish. Environ Pollut 205:145-152

46. Kotyzova D, Eybl V, Mihaljevic M et al (2005) Effect of long-term administration of arsenic (III) and bromine with and without selenium and iodine supplementation on the element level in the thyroid of rat. Biomed Pap Med Fac Univ Palacky Olomouc Czech Repub 149:329-333 